\title{
Determinants of Credit Infections: Evidence from Banking Sector in an Emerging Economy
}

\author{
Ayesha Afzal ${ }^{*}$, Nawazish Mirza ${ }^{* *}$,Azka Mir ${ }^{* * *}$
}

\begin{abstract}
This paper applies dynamic panel estimates on 22 commercial banks in Pakistan to determine the factors that affect their asset quality. Consequently, the study tests for a comprehensive array of both bank-specific and macroeconomic variables collected quarterly from 2008 to 2016. The empirical analysis confirms that bad asset quality can be explained by retarded GDP growth and unfavorable movement in exchange and lending rates. Within the bank-specific variables, non-performing loans are the most responsive to loans to the agriculture and energy sectors, level of capitalization, size of the lending institution and quality of management.
\end{abstract}

Keywords: Asset quality, banking risks, non performing loans, credit risk

JEL Classifications: G20, G21, G29.

\section{Introduction}

Banks face many risks that, if materialized, could lead to financial distress and systematic failure. One such risk is the credit risk. By definition credit risk derives from the expectation that some of the firm's assets will decline in value and perhaps become worthless. As of December 2016, the operations of 34 commercial banks in Pakistan had extended total advances of Rs 5403.2 billion, equivalent to $15.6 \%$ of the GDP of the country (Statistical Supplement, State Bank of Pakistan, 201617). The importance of the banking system in Pakistan is furthered by the absence of a developed and efficient capital market. Its role in the allocation of funds in the economy cannot be overemphasized, and it is imperative that the banking system remains stable and solvent.

\footnotetext{
* Assistant Professor, Lahore School of Economics, Lahore, Pakistan.

** Associate Professor of Finance, S P Jain School of Global Management, Dubai, UAE.

*** Teaching and Research Fellow, Lahore School of Economics, Lahore, Pakistan.
} 
To mitigate the risk, banks follow strict credit risk management policies under exhaustive guidelines specified within the Prudential Regulations of the State Bank of Pakistan4. Despite these stringent regulations, there is a continued occurrence of non-performing loans (NPLs), as measured in terms of asset quality in the bank's portfolio.

In December 2016 the total NPLs of banks in Pakistan were valued at Rs. 631 billion, about $62 \%$ of which were of private commercial banks (Statistical Supplement, State Bank of Pakistan, 2016-17). The presence of these bad loans leads to decreased profit margins for individual banks, and increased solvency risk of the entire banking system. A failure of the banking system would have unprecedented effects in the real economy, which would lead to long-term economic distress. This is evidenced by Nkusu (2011) who found that NPLs link credit markets to macro-economic performance for 26 developed countries in the period 1998-2009.

The determinants of NPLs have been explored quite extensively for banking systems around the world. Polodoo et al. (2015) conducted a study on the ten banks in Mauritius from 2000-2012 to determine the main factors impacting NPLs. They used both bank-specific and macroeconomic determinants for analysis. Findings indicated that critical variables were sector-wise credit concentration and cross-border lending. In Pakistan, there is also evidence of sector-wise concentration. The largest amount of credit extended by commercial banks is to the manufacturing sector, amounting to Rs 1644.5 billion, constituting about $39 \%$ of total lending to private sector enterprises (Statistical Supplement, State Bank of Pakistan, 2016-17). The Energy Sector and Commerce and Trade follow with $6 \%$ and $5.3 \%$ respectively.

Louzis et al. (2011) found the bank-specific and macroeconomic determinants of NPLs among nine Greek commercial banks for the period of 2003-2009, separating the loans into consumer, business, and mortgage loan categories. . The variation in NPLs in their sample is largely explained by the external factors of GDP, unemployment, interest rate, and public debt and the internal factor of management quality. They also found that the impact of these external factors varies among the loan categories, with mortgage loans showing the least response.

Macit (2017) investigated the determinants of the NPL ratio for Turkey using quarterly data from 15 of the country's largest commercial banks. The data ranging from 2005 to 2010 show that well-capitalized banks tend to have a higher ratio, similar to banks with a greater interest margin. The paper argues that banks which are better able to diversify are 
able to reduce their NPL ratio. The study also showed that GDP growth and foreign exchange rates also impact the performance of loans in Turkey.

Literature on the subject is further enhanced by Abid et al. (2014) who also found that management quality and macroeconomic factors are the major determinants of non-performing loans in Tunisian commercial banks. Their results are taken from a sample of 16 Tunisian banks from2003-2012. Akinlo and Emmanuel (2014) in Nigeria and Khemraj and Pasha (2009) in Guyana also found macroeconomic variables of GDP, exchange rate, and interest rate to be the most important factors determining the level of NPLs. The same results were confirmed for Italian commercial banks by Bofondi and Ropele (2011).

Moreover, using bank-specific as well as country-specific variables, Dimitrios et al. (2016) examined the determinants of NPLs in 15 European countries over 25 years from 1990-2015. Their findings conclude that Return on Equity (ROE) affects the NPLs in the same time period, as well as with a lag. Similarly, Return on Assets (ROA), economic growth, the output gap, and tax income affect NPLs significantly; emphasizing that macroeconomic condition can significantly affect the performance of banks.

Zaib et al (2014) attempt to explain the determinants of NPLs for Pakistani banks from 2003-2011. They drew from panel data of eight banks using bank-specific factors: bank size, risk profile, and management; and macroeconomic variables: GDP growth, exchange rate, lending rate, inflation, and unemployment. They found that GDP growth, risk profile, and management significantly explained the NPLs within the banking system.

Beck et al. (2013) emphasize the role of efficient capital markets and nominal exchange rates as significant variables in explaining variation in NPLs across 75 countries; GDP growth, share prices, and bank lending rate were also important variables. The results of De Bock and Demyanets (2012) had similar findings for 25 developing economies from 1996-2010. In addition to the variables identified by Beck et al. (2013), De Bock and Demyanets (2012) found that terms-of-trade also affects the level of NPLs. In the absence of a developed and efficient capital market, banks in Pakistan cater to more than $99 \%$ of all corporate financing needs as shown in Table 1. This further enhances the significance of a solvent banking system as any adverse shocks to bank stability will have a devastating impact on the real economy. 
Table 1: Role of Financial Intermediaries vs Capital Markets

\begin{tabular}{lccccc}
\hline Years & $\begin{array}{c}\text { Funds raised } \\
\text { ipos/spos (bn Rs) }\end{array}$ & $\begin{array}{c}\text { Tfc } \\
\text { (bn Rs) }\end{array}$ & $\begin{array}{c}\text { Bank } \\
\text { (bn Rs) }\end{array}$ & Total & Percentage \\
\hline 2011 & 8.10 & 4.00 & 2364.50 & 2376.60 & 99.49 \\
2012 & 10.31 & 6.30 & 2393.10 & 2409.71 & 99.31 \\
2013 & 7.60 & 6.00 & 2414.00 & 2427.60 & 99.44 \\
2014 & 14.89 & 7.80 & 2695.50 & 2718.19 & 99.17 \\
2015 & 11.28 & 0.00 & 2859.50 & 2870.78 & 99.61 \\
2016 & 8.13 & 3.00 & 2933.04 & 2949.63 & 99.44 \\
\hline
\end{tabular}

Source: SECP and SBP annual reports 2016

The link can be explained by the failure of the banking system to act as a conduit to transfer resources from surplus units to deficit units. At best, a rise in the issuance of bad loans leads to a reduction in the supply of credit, and in the extreme, bank failure and a system-wide contagion impeding efficient resource allocation and economic growth. Figure 1 shows that the credit infection for banks in Pakistan in absolute rupee terms has been trending largely upward since 2010 .

\section{Figure 1: Non-Performing Loans in PKR}

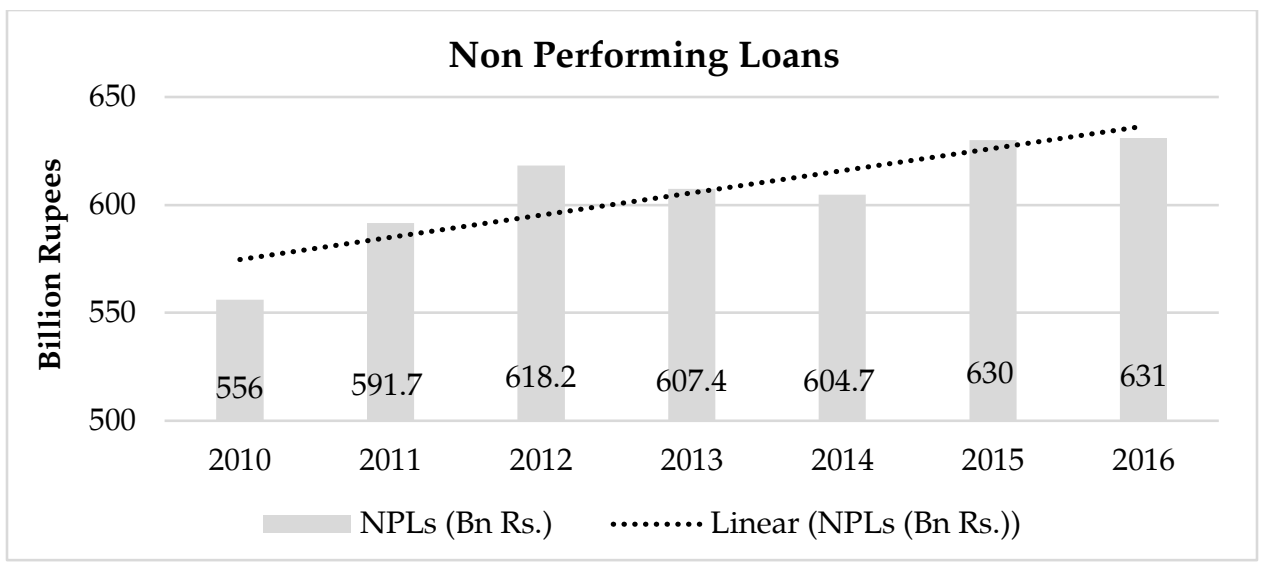

Source: SBP Annual Reports

It is imperative for banking system regulators and policy planners to know what factors give rise to NPLs in Pakistan. This should allow for the adoption of effective regulatory mechanisms to reduce the occurrence of NPLs and ensure continued solvency of the system.

This study adds to the existing literature by selecting a very comprehensive list of independent variables representing both systematic 
and idiosyncratic determinants of bank risk. Moreover, this paper undertakes the research within the time-frame of the post-financial reform to ensure that all changes have been well-implemented and their impact can be effectively studied for all private commercial banks operating within Pakistan. It provides results that can be used for efficient policy-making and impact-analysis by the regulatory authority.

\section{Research Methodology}

This section focuses on the research methodology which includes variables, data and econometric models.

\subsection{Data and Econometric Model}

The bank-specific data required for this study have been gathered from quarterly financial statements of commercial banks operating in Pakistan for the period of 2008-2016. Our sample does not include any public sector-owned banks as their inherent contractual guarantees provide them less incentive to diversify risk. Banks that have been delisted or merged were also excluded from the analysis. Based on this criteria we have a balanced panel of 22 commercial banks. The macroeconomic data have been gathered from various issues of the Pakistan Economic Survey, State Bank of Pakistan Statistics, and World Development Indicators.

\subsection{Variables}

\subsubsection{Dependent Variable}

Prudential regulations of the State Bank of Pakistan define NPLs and their required financial statement treatment ${ }^{5}$. These regulations are taken into consideration for the purpose of this analysis as they deal exclusively with the lending departments of banks, focusing primarily on larger loans. Theoretically, as discussed in the literature above, the probability of default on such loans is fairly high. According to the literature, asset quality of a bank is measured by the ratio of NPLs to total loans.

\subsubsection{Independent Variables}

The paper aims to analyze the determinants of NPLs affecting the asset quality of banks in Pakistan. For this purpose both bank specific and macroeconomic variables are utilized. 


\subsubsection{Bank-Specific Variables}

\subsubsection{Return on Equity}

Return on Equity (ROE) is a measure of the bank's profitability derived from shareholders equity. It is a good measure for evaluating the bank's management performance. According to Salas (2002), bankspecific variables like ROE can be indicative of a possible rise in NPLs in the future. In order to test this, the lagged values of ROE will be used for evaluating how a bank's past management performance can have an impact on the current NPLs. Lagged value of ROE will be used as a proxy for a bank's past management quality. As the paper uses a yearly panel to analyze the determinants of NPLs, one year lag of bank-specific variable will be taken to analyze how past performance affects NPLs. According to a study by Louizs (2012), there is a negative relationship between management performance and NPL. Similarly, past performance, measured by using lags of ROE, has a negative relationship with current NPLs. Abid (2014) found that past management performance is negatively related to the current NPLs.

\subsubsection{Capital Adequacy Ratio}

Capital Adequacy Ratio (CAR) is a measure of a bank's eligible capital compared to its risk-weighted assets. This ratio is important for analyzing the bank's capacity to cope with the risk of losses that may arise. The CAR for all banks has been taken from their financial statements.

A lower value of CAR suggests a low capitalization level for a bank, which may result in high levels of NPLs. Moral hazard action by the manager may cause a bank to take excessive risk by lending out to risky borrowers, leading to increases in the volume of NPLs. As mentioned above, CAR is a bank-specific variable. Its lag will be considered in order to evaluate how a bank's previous year's risk measure impacts the current NPL ratio.

\subsubsection{Size $(\ln T A)$}

A larger bank is expected to have a lower credit risk compared to smaller banks. This could be attributed to opportunity for diversification and the resultant quality of credit portfolio. Larger banks have more opportunity to avoid concentration in advances, thereby reducing loan 
losses. $\mathrm{Hu}$ et al. (2004) assert that larger banks incur economies of scale when analyzing borrower data for both pre- and post-disbursement of the loan. Therefore, the NPLs of larger banks are expected to be lower. Similarly, Abid (2014) expect the relationship between bank size and NPLs to be negative.

However, other studies find a positive association between bank size and NPLs. Polodoo et al. (2015) and Rajan and Dhal (2003) suggest an increase in bad loans as the size of the bank increases due to complexity and the volume of their advances. This hypothesis suggests that large banks tend to be more lenient in extending credit and taking on more risk in their portfolio. This gives rise to the Too Big To Fail (TBTF) situation as discussed by Louzis (2012). In this case, the imposition of market discipline by related stakeholders becomes weak, and banks tend to indulge in the moral hazard of lending to less-than-optimal borrowers.

Based on the literature, this paper expects to find either of these two associations of bank size with NPL ratio.

\subsubsection{Lagged Total Loans}

Bad loans are expected to occur in subsequent years of their dispersion. This is because of the prevalent uncertainty in the economic and political environment, which could adversely affect performance of businesses and force them to default on their obligations. This view is supported by Polodoo et al (2015) who find this to be a significant variable in explaining the occurrence of NPLs. This study expects a positive relationship between the NPLs and lagged total loans.

\subsubsection{Sectoral Concentration}

Banks tend to lend the most to the high-earning sectors of the economy to ensure better returns on their credit portfolios, as explained by Afzal and Mirza (2012). This could lead to concentration in the loan portfolio and could expose banks to high risk in case of an adverse movement in the performance of that sector. Keeton and Morris (1987) find a significant impact of credit concentration on NPLs.

This study takes sectoral advances to Textile, Energy, and Agriculture sectors by sample banks, similar to a previous study by Afzal and Mirza (2012) These sectors receive the most credit from the banking system and are also most prone to effects from prices and supply of 
electricity, POL, and water; their financial position may vary greatly over the life of the loan. A positive relationship is expected between concentration of credit to each of these sectors and the occurrence of NPLs.

\subsubsection{Leverage Ratio: Total liabilities/ Total Assets}

Banks are expected to take higher risks by soliciting more funds and extending excessive credit to increase their returns. This is more likely to hold for banks with a larger asset base and a wider outreach than smaller banks. However, smaller banks would have the incentive to take excessive risks by increasing their leverage ratio in order to increase their income. This paper expects a positive relationship between leverage ratio and asset quality.

\subsubsection{Indebtedness: Total Loans to Private Sector/GDP}

In times of economic growth banks tend to lend heavily to the expanding private sector as discussed by Nkusu (2011). They may relax their risk management practices to earn higher returns. However, an adverse economic shock may lead the private sector firms into debt repayment issues, thereby causing financial distress to the banking sector. We expect a positive relation between indebtedness and NPL ratio.

\subsubsection{Macroeconomic Variables}

\subsubsection{GDP Growth}

The relationship between the phases of the business cycle and credit defaults has been confirmed in the literature many times. As incomes fall, borrowers are unable to meet their debt obligations and the NPLs of the banking system rise (Quagliariello 2007; Salas and Saurina 2002). This study expects a negative effect of GDP growth on the bad debts of banks.

\subsubsection{Inflation}

According to the literature, there appears to be a significant and positive relationship between rate of inflation and NPLs. Whenever the economy experiences low levels of inflation, there will be less volatile inflation, so there is less probability of the unexpected which decreases the probability of falling into arrears. Over the long run, with low levels of volatility of inflation, the performance of arrears has been improved. With increasing price levels, the ability of the borrowers to pay back loans 
decreases. In a study on Pakistan, Rizvi \& Khan (2015) used a quadratic regression and found that the level of inflation impacts NPLs both negatively and positively. Inflation reduces the purchasing power of consumers which consequently reduces economic growth.

\subsubsection{Unemployment \& Lending Rate}

The link between NPLs, lending rate, and unemployment could be seen through the life-cycle consumption model. According to this model, individuals within a low income bracket have a higher probability of default because of increased possibility of being unemployed. Lowincome individuals with increased risk of being unemployed increase the chances of NPLs for the bank.

A higher loan rate will reduce the borrower's capacity for repayment, therefore the probability of loan default increases. Studies by Akinlo and Emmanuel (2014) and Nkusu (2011) find that a higher interest rate leads to an increase in the level of NPLs. Banks often charge higher interest rates to risky borrowers which already have a substandard record of repayment. This increases the chances of NPLs. This paper takes an annual average of Karachi Interbank Offer Rate (KIBOR) as the explanatory interest rate. This is the rate at which credit is extended by banks in Pakistan under the new market-based regime.

\subsubsection{Exchange Rate}

Banks are likely to incur a higher level of loan losses in the case of an adverse movement in exchange rates. This would be especially true for banks who have lent in foreign exchange to unhedged borrowers, or if banks have an exposure to foreign currency and trade transactions. De Bock and Demyanets (2012) confirmed this relationship for 25 developing countries. Beck et al. (2013) also confirmed the positive association of adverse movements in exchange rate with an increase in NPLs for both advanced and emerging economies. This paper takes the exchange rate of Pak Rupee with the dollar and expects a negative relationship with NPLs.

\subsection{Econometric Specification}

The fixed effects model will be used to analyze the impact of bank-specific and macro-variables on NPLs. , This model allows controlling for unobserved heterogeneity across banks. While this approach is rather simple and intuitive, it may give rise to "dynamic 
panel bias", which results from the possible endogeneity of the lagged variable and the fixed effects in the error term. This can be avoided by applying the "difference GMM" method of Arellano and Bond (1991), which is designed for panel data having: 1) few time periods and greater number of individual entities; 2) dynamic left-hand-side variable, depending on its own lagged values; and 3) independent variables that are not strictly exogenous, suggesting that they are correlated to the past and/or current error terms. This technique transforms the data to first differences to remove the fixed-effect element and uses the lagged levels of the right-hand-side variables as instruments.

$$
\begin{gathered}
\Delta N P L_{i t}=\alpha \Delta N P L_{i t-1}+\sum_{j=0}^{1} \beta_{1 j} \text { exchangerate }_{t-j}+\sum_{j=0}^{1} \beta_{2 j} \Delta \pi_{t-j} \\
+\beta_{3 j} \text { KIBOR }_{t}+\sum_{j=0}^{1} \beta_{6 j} G D P_{t-j}+\sum_{j=0}^{1} \beta_{4 j} X_{i t-j} \\
+\sum_{j=0}^{1} \beta_{5 j} Y_{i t-j}+\mu_{t}+\varepsilon_{i t}
\end{gathered}
$$

$\pi$ is the change in the inflation rate. $X$ is the matrix of all the bank-specific variables that will be included. $Y$ is the matrix for the percentage share of total loans to the three selected sectors. A lag of one year for all the variables is used in the regression equation. Table 2 presents the summary of explanatory variables and their expected signs. 
Table 2: Summary of Explanatory Variables

\begin{tabular}{|c|c|c|c|}
\hline $\begin{array}{l}\text { Bank specific } \\
\text { variables }\end{array}$ & Quantification & Hypothesis & $\begin{array}{l}\text { Expected } \\
\text { sign }\end{array}$ \\
\hline ROE & Profits/Total Equity & $\begin{array}{l}\text { Bad Management: } \\
\text { Low cost efficiency is } \\
\text { positively associated with } \\
\text { increase in future NPLs }\end{array}$ & $(-)$ \\
\hline CAR & $\begin{array}{l}\text { Owned Capital/Total } \\
\text { Assets }\end{array}$ & $\begin{array}{l}\text { Moral Hazard : } \\
\text { Low capitalization leads to } \\
\text { an increase in NPLs }\end{array}$ & $(-)$ \\
\hline Size & Ln of Total Assets & $\begin{array}{l}\text { Diversification \& TBTF: } \\
\text { Diversification is negatively } \\
\text { related to NPLs while Moral } \\
\text { Hazard of TBTF leads to } \\
\text { higher risk }\end{array}$ & $(-)(+)$ \\
\hline $\begin{array}{l}\text { Lagged Total } \\
\text { Loans }\end{array}$ & Lag of Total Loans & & $(+)$ \\
\hline Leverage Ratio & $\begin{array}{l}\text { Total Liabilities/Total } \\
\text { Assets }\end{array}$ & & $(+)$ \\
\hline Loans to Textile & $\begin{array}{l}\text { Loans to Textile/Total } \\
\text { Loans }\end{array}$ & $\begin{array}{l}\text { Credit Concentration: } \\
\text { Higher concentration, higher ri }\end{array}$ & $(+)$ \\
\hline Loans to & Loans to & & $(+)$ \\
\hline Agriculture & $\begin{array}{l}\text { Agriculture/Total } \\
\text { Loans }\end{array}$ & & \\
\hline Loans to & Loans to Energy/ & & $(+)$ \\
\hline Energy & Total Loans & & \\
\hline Indebtedness & $\begin{array}{l}\text { Loans to Pvt } \\
\text { sector/GDP }\end{array}$ & & \\
\hline
\end{tabular}

\begin{tabular}{|c|c|c|c|}
\hline $\begin{array}{l}\text { Macroeconomic } \\
\text { variables }\end{array}$ & Quantification & Hypothesis & $\begin{array}{c}\text { Expected } \\
\text { signs }\end{array}$ \\
\hline Economic growth & GDP growth rate & & $(-)$ \\
\hline Inflation & Inflation rate & & $(+)$ \\
\hline Unemployment & Unemployment rate & & $(+)$ \\
\hline KIBOR & Average KIBOR & & $(+)$ \\
\hline Exchange rate & Average exchange rate & & $(-)$ \\
\hline
\end{tabular}

\section{Empirical Results and Discussion}

The current study conducted a lag one-step GMM coefficients estimation for the first model that included all the bank-specific and macroeconomic variables. The estimation used the variables as regressors, while up to three lags of all variables were used as instruments. The results show that the performance of the economy as measured by GDP growth and unemployment. These findings are significant at $5 \%$ and $1 \%$ respectively, and negatively related to the asset quality of the banks. An increase in KIBOR increases the non- 
performance on the loan portfolio, as does an adverse movement in the exchange rate. Both explanatory variables are highly significant at $1 \%$. These findings conform to the expected signs and theoretical discussion in the previous section.

Table 3: Regression Results

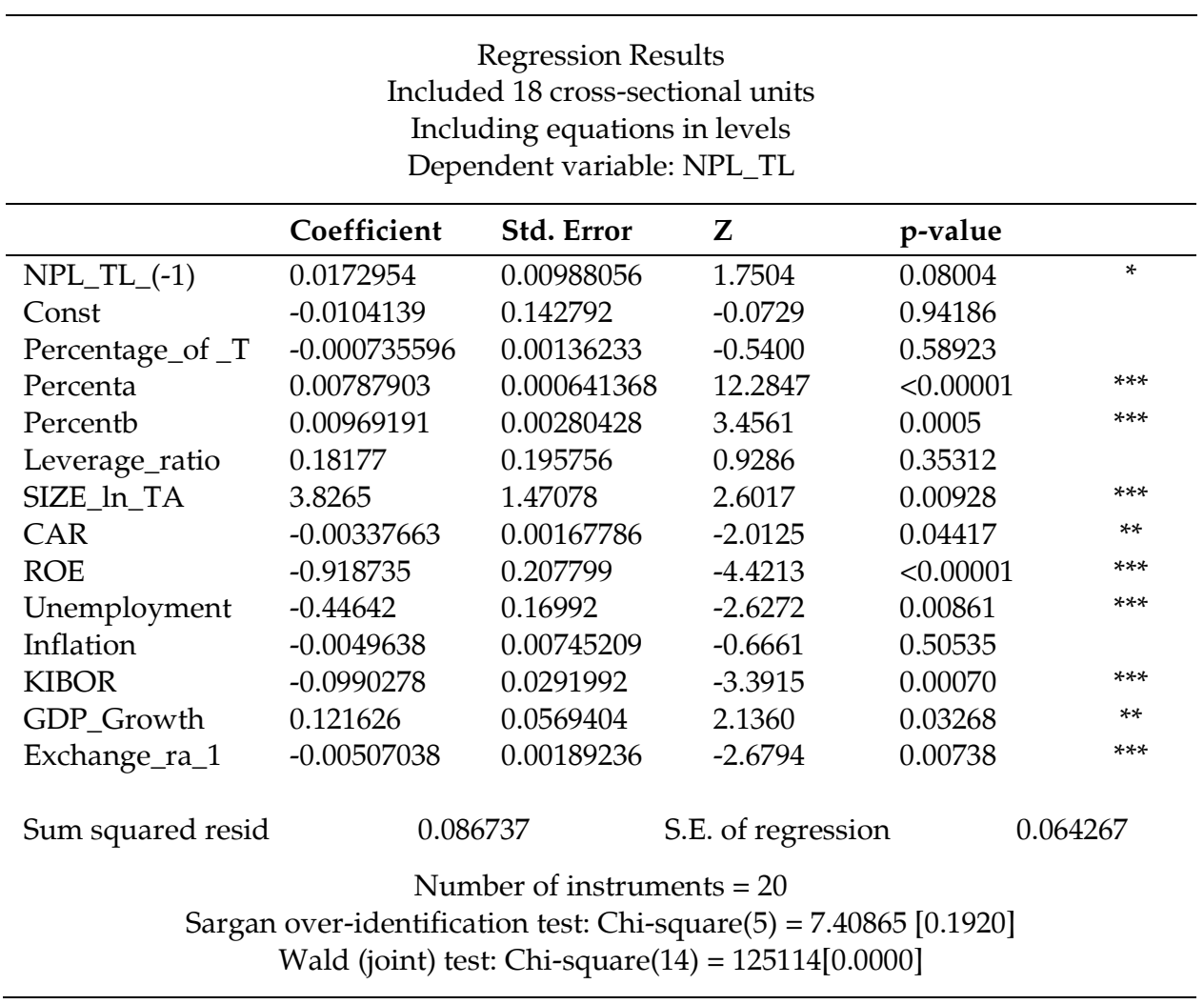

The paper also finds strong evidence of bank-specific variables having a profound impact on the asset quality. The share of advances extended to agriculture in total loans, and energy in total loans have a positive and significant relation to changes in NPL. This implies that banks have to diversify their credit portfolios in order to reduce the risk inherent in the nature of agriculture businesses. Contrary to expectation, the coefficient of share of textiles as a percentage of total loans has a negative relationship with asset quality even though it is not significant. This could be explained largely by the fact that the textile sector is the largest borrower from the banks, and they are treated as such: loans may be extended on favorable terms to maintain a long-term relationship. Moreover, manufacturing, of which textiles is a sub sector, is the single 
largest contributor to the GDP of Pakistan. It may be less immune to cyclical anomalies and external shocks.

The size variable is positive and highly significant. This is supporting the Too Big To Fail Hypothesis whereby banks are becoming bigger through mergers and acquisitions as a policy of consolidation followed by the State Bank of Pakistan. However, in the process, banks may be extending high-risk credits to earn greater returns.

Bank profitability is a major function of management efficiency. This is further confirmed through the negative relationship between ROE and asset quality. A more pro-active management is able to make appropriate decisions with regards to sources and uses of funds. A wellperforming credit portfolio would ensure better asset quality. This is further confirmed by the negative relationship between CAR and NPLs. A better-capitalized bank has a better asset quality.

The results remained robust when taking first difference of all the explanatory variables. The Sargan over-identification test and Wald test demonstrate that the model is accurate.

\section{Policy Implications and Conclusion}

Empirical results show a strong relationship between the macroeconomic performance of the economy and the asset quality of banks. This pro-cyclical behavior means that the regulators can predict the performance of banks based on position of the economy on the business cycle. In case of an eminent slow down, regulators can play a proactive role in strengthening the solvency position of banks through tightening liquidity and capital requirements, as well as imposing stringent risk management practices.

Within the bank-specific variables, share of loans to the agriculture sector has shown a positive relationship with deterioration in asset quality. This could be due largely to the unpredictable and seasonal nature of the farming business. Moreover, the access to formal credit has remained limited to this primary sector in the absence of specific regulations by the State Bank of Pakistan (SBP). However, the situation is now expected to improve as a result of the prudential regulations for the agriculture sector introduced by SBP in 2005 and revised in 2014.Given the empirical findings, banks should impose more stringent criteria of risk management and credit evaluation when extending agriculture credit. 
Bank performance as measured by ROE and capitalization CAR is related to quality of management. This study provides both the banks and the regulators tools to identify the problem areas and take requisite action. The consolidation of the banking system in Pakistan through mergers and acquisitions may give rise to the TBTF moral hazard actions causing banks to relax their credit evaluation procedures and increase the systematic risk. It is suggested that regulatory authority be vigilant about the risk management practices of larger, as well as smaller, banks. 


\section{References}

Abid, L., Ouertani, M. N., \& Zouari-Ghorbel, S. (2014). Macroeconomic and bank-specific determinants of household's non-performing loans in Tunisia: A dynamic panel data. Procedia Economics and Finance, 13, 58-68.

Afzal, A., \& Mirza, N. (2012). Interest rate spreads in an emerging economy: The case of Pakistan's commercial banking sector. Economic Research-Ekonomska Istraživanja, 25(4), 987-1004.

Afzal, A., \& Mirza, N. (2012). Size, diversification and risk: Preliminary evidence from commercial banks in Pakistan. Pakistan Journal of Commerce and Social Sciences, 6(2), 282-296.

Akinlo, O., \& Emmanuel, M. (2014). Determinants of non-performing loans in Nigeria. Accounting \& Taxation, 6(2), 21.

Arellano, M., \& Bond, S. (1991). Some tests of specification for panel data: Monte Carlo evidence and an application to employment equations. The Review of Economic Studies, 58(2), 277-297.

Beck, R., Jakubik, P., \& Piloiu, A. (2013). Non-performing loans: What matters in addition to the economic cycle? Working Paper Series 1515, European Central Bank.

Bofondi, M., \& Ropele, T. (2011). Macroeconomic determinants of bad loans: Evidence from Italian banks. Bank of Italy Occasional Paper, (89).

De Bock, R., \& Demyanets, M. A. (2012). Bank asset quality in emerging markets: Determinants and spillovers. International Monetary Fund, (No. 12-71).

Dimitrios, A., Helen, L., \& Mike, T. (2016). Determinants of nonperforming loans: Evidence from Euro-area countries. Finance research letters, 18, 116-119.

Hu, J. L., Li, Y., \& Chiu, Y. H. (2004). Ownership and nonperforming loans: Evidence from Taiwan's banks. The Developing Economies, 42(3), 405-420.

Keeton, W., \& Morris, C. S. (1987). Why do banks' loan losses differ? Economic Review, 72(5), 3-21. 
Khemraj, T., \& Pasha, S. (2009). The determinants of non-performing loans: An econometric case study of Guyana. University Library of Munich, Germany, MPRA Paper 53128.

Louzis, D. P., Vouldis, A. T., \& Metaxas, V. L. (2012). Macroeconomic and bank-specific determinants of non-performing loans in Greece: A comparative study of mortgage, business and consumer loan portfolios. Journal of Banking \& Finance, 36(4), 1012-1027.

Macit, F. (2017). What determines the non-performing loans ratio: Evidence from Turkish commercial banks. CEA Journal of Economics, 7(1).

Nkusu, M. (2011). Nonperforming loans and macrofinancial vulnerabilities in advanced economies. IMF Working Papers, 1-27.

Polodoo, V., Seetanah, B., Sannassee, R. V., Seetah, K., \& Padachi, K. (2015). An econometric analysis regarding the path of non-performing loans: A panel data analysis from Mauritian banks and implications for the banking industry. The Journal of Developing Areas, 49(1), 53-64.

Quagliariello, M. (2007). Banks' riskiness over the business cycle: A panel analysis on Italian intermediaries. Applied Financial Economics, 17(2), 119-138.

Rajan, R., \& Dhal, S. C. (2003). Non-performing loans and terms of credit of public sector banks in India: An empirical assessment. Occasional Papers, 24(3), 81-121.

Rizvi, W., \& Khan, M. M. S. (2015). The impact of inflation on loan default: A study on Pakistan. Australian Journal of Business and Economic Studies, 1(1).

Salas, V., \& Saurina, J. (2002). Credit risk in two institutional regimes: Spanish commercial and savings banks. Journal of Financial Services Research, 22(3), 203-224.

Statistical Supplement 2016-2017. (2017). Annual Report. State Bank of Pakistan. Available

at: http://www.sbp.org.pk/reports/annual/arFY17/annex_index.htm.

Zaib, A., Farid, F., \& Khan, M. K. (2014). Macroeconomic and bankspecific determinants of non-performing loans in the banking sector in Pakistan. International Journal of Information, Business and Management, 6(2), 53. 